\title{
Role of parents in adolescent self-rated health: Norwegian Nord-Trøndelag Health Study
}

\author{
This article was published in the following Dove Press journal: \\ Adolescent Health, Medicine and Therapeutics \\ 4 September 2010 \\ Number of times this article has been viewed
}

\author{
Hans-Johan Breidablik' \\ Eivind Meland' \\ Turid Lingaas Holmen ${ }^{2}$ \\ Stian Lydersen ${ }^{3}$ \\ 'Department of Public Health and \\ Primary Health Care, Section for \\ General Practice, University of \\ Bergen, ${ }^{2}$ HUNT Research Centre, \\ Department of Public Health and \\ General Practice, Faculty of Medicine, \\ ${ }^{3}$ Unit for Applied Clinical Research, \\ Department of Cancer Research \\ and Molecular Medicine, Norwegian \\ University of Science and Technology, \\ Trondheim, Norway
}

Correspondence: Hans-Johan Breidablik Department of Research and Development, District General Hospital of Førde, Førde, Norway Tel +4790182853

Fax +4757839015

Email hans.johan.breidablik@helse-forde.no
Background: Self-rated health $(\mathrm{SRH})$ is a known important predictor of later mortality, morbidity, and health service attendance. From adolescence onwards, this multifactorial composite seems to be relatively stable. Therefore, it is important to study how SRH is also shaped and influenced by parental factors.

Methods: Analyses were based on data from the Nord-Trøndelag Health studies in Norway during 1995-1997 among adolescent children aged 13-19 years and their parents. Cross-table analyses were made for parental and adolescent SRH. Proportional odds logistic regression analyses with parental SRH and a broad spectrum of other parental covariates were conducted, with adolescent SRH as the dependent variable, both unadjusted and adjusted.

Results: Lower level of education, living alone, smoking, low general well being, and low life satisfaction were the most important parental factors associated with lower SRH in adolescents. However, the associations between parental SRH and adolescent SRH were rather weak, and in adjusted multivariable analyses lost significance for both genders. The net effect of genetics and early vertical family influence on adolescents' SRH thus seems to be moderate. Notably, the association between more specific health-related and lifestyle variables in parent and adolescent SRH was rather weak.

Conclusion: SRH in adolescents seems to be shaped only partly by parental influence, and is less "deterministic" than might be expected from some genetic studies. SRH may therefore be modifiable by health-promoting efforts in early life.

Keywords: self-rated health, parents, adolescents, children, parent-child relationship

\section{Introduction}

The World Health Organization defines health as a resource for living a productive life, and considers self-rated health (SRH) to be a more appropriate measure of adolescent health than traditional morbidity and mortality measures. ${ }^{1}$ Among adults, SRH is a known important predictor of later mortality, morbidity, and health service attendance, and is also associated with sickness absence from work. ${ }^{2}$ Childhood and adolescence are important stages in life for possible control over diseases, particularly those with strong psychosocial components. ${ }^{3}$ The Council of the European Union states that "parents play a vital role in the well being and healthy environment of young people". ${ }^{4}$

In an earlier study based on the same Nord-Trøndelag Health (HUNT) study material from Norway, the authors found adolescent SRH to be a multifactorial composite associated with a broad spectrum of medical, psychologic, social, and lifestyle factors for both genders. ${ }^{5}$ A further longitudinal study also showed SRH to be a relatively stable construct during adolescence, and one that deteriorated consistently with a lack 
of general well being, disability, and health-compromising behavior. ${ }^{6}$ Thus, if SRH is best understood as an enduring self-concept, and found to be mainly established prior to adolescence, an important question is to what extent it could be inherited genetically or socially from parents.

In adolescence, individuals are influenced by genes (genetically inherited vulnerability), the early "vertical" influence of parents and family, and later the increasing demands from and influence of peers, school, and wider society, including mass media ("horizontal" influence). The various factors probably also interact, but for effective health promotion aimed at improving SRH among adolescents, it is useful to know which of these three influences is most important during this period.

A longitudinal Finnish twin study found 63\% heritability of SRH at the age of 16 years, declining to $33 \%$ at the age of 25 years. The residual variation was due to unshared environments. ${ }^{7}$ Furthermore, Romeis et al found in American male twins that over one third of the variability in SRH could be attributed to genes, and that health conditions accounted for only $15 \%$ of the variation. ${ }^{8}$

In contrast, other twin studies from Scandinavia have concluded that environmental factors are the dominant explanation, accounting for $60 \%-90 \%$ of the variation in SRH. ${ }^{9-11}$ Leinonen et al from Finland concluded that there were no specific genetic effects on SRH, but an influence through the effect on chronic diseases, functional limitation, and mood. ${ }^{12}$

Given this background, the objectives of the present study were firstly to examine the association between parental SRH and adolescents' SRH and, secondly, to identify other parental factors possibly associated with adolescent SRH.

\section{Material and methods Study populations}

In 1995-1997, the county of Nord-Trøndelag in central Norway had approximately 127,000 inhabitants. In this period, all inhabitants aged 13 years and older were invited to join a large population study, the second Nord-Trøndelag Health (HUNT 2) study, and approximately 70,000 (70\%) participated.

Students at junior and senior high schools, aged 13-19 years, were invited to participate in the adolescent part of the study, known as Young-HUNT 1. A total of 9131students participated, representing a $90 \%$ response rate. Data on SRH from mothers who participated in HUNT in 1995-1997 were available for 7092 adolescents, while data on SRH from fathers were available for 6008 adolescents. Merging of data from adolescents and their parents participating in the HUNT study was made possible through the Norwegian Family Register using the 11-digit personal number by which every Norwegian citizen is registered.

\section{Methods}

The results from the adult and the adolescent populations were linked, enabling comparison of factors between the parents and their adolescent children. All HUNT participants completed questionnaires and attended a clinical examination, including measurement of weight and height. The questionnaires included questions on somatic and mental health, lifestyle, quality of life, use of medication, and use of health services (http://www.ntnu.no/hunt/english/data/que). Height and weight were measured without shoes by specially trained nurses using standardized equipment and protocols. Details about the study have been reported previously. ${ }^{13}$

Adolescents in Young-HUNT completed the self-administered questionnaire during one school hour in an examination setting. The dependent variable in this study was based on the self-reported global health question: "How is your overall health at the moment?" The question had four answer categories, ie, "very good", "good", "not very good", and "poor". The predictor variables, except for the age of the adolescent, were the parents' answers to the questionnaires and the BMI results from 1995-1997.

Table 1 shows the list of questions used as dependent and predictor variables in our analyses. Some of these were single items, but most of the predictor variables were composite scores constructed from a set of questions. These covered both somatic and psychologic health, disability, general mood and well-being, health-related lifestyle, education level, and marital status. Subjective health complaints were assessed on an eight-question scale for common psychosomatic symptoms. Psychologic (mental) health, a measure of anxiety and depression, was based on a short version of the SCL-25. ${ }^{14}$ Four questions on self-esteem were based on Rosenberg's scale. ${ }^{15}$ General well being was a five-item quality of life scale validated in earlier HUNT studies. ${ }^{16}$ For mental health complaints and general well being, Cronbach's alphas are given in Table 1, showing acceptable internal consistencies. All answers were recoded to yield the same direction (increasing values for increasing problems) in the composite scores.

All participants gave their written consent to participate in the study. For students under 16 years of age, parents also 
Table I Variables used in the analyses, including response options and Cronbach's alphas for the two psychometric sum scores

\begin{tabular}{|c|c|c|}
\hline Dependent variable & $\begin{array}{l}\text { Response } \\
\text { options }\end{array}$ & $\begin{array}{l}\text { Cronbach's } \\
\text { alpha }\end{array}$ \\
\hline How is your health at the moment? & 4 & \\
\hline \multicolumn{3}{|l|}{ Independent variables } \\
\hline Gender (parents and adolescents) & 2 & \\
\hline Age (adolescents in years) & Number & \\
\hline How is your health at the moment? & 4 & \\
\hline What is your highest level of education? & 5 & \\
\hline \multicolumn{3}{|l|}{-Secondary school, 7-10 years } \\
\hline \multicolumn{3}{|l|}{-High school, intermediate, I-2 years } \\
\hline \multicolumn{3}{|l|}{-Junior college, qualifying) } \\
\hline \multicolumn{3}{|l|}{-University less than four years } \\
\hline \multicolumn{3}{|l|}{-University/college more than four years } \\
\hline Do you live alone or with & 2 & \\
\hline \multicolumn{3}{|l|}{ others (spouse or partner)? } \\
\hline \multirow{2}{*}{\multicolumn{3}{|c|}{$\begin{array}{l}\text { Do you suffer from or have you suffered } \\
\text { from any of the following illnesses? }\end{array}$}} \\
\hline & & \\
\hline -Asthma & 2 & \\
\hline -Myocardial infarction (heart attack) & 2 & \\
\hline -Angina pectoris (chest pain) & 2 & \\
\hline -Stroke or cerebral hemorrhage & 2 & \\
\hline -Diabetes & 2 & \\
\hline -Epilepsy & 2 & \\
\hline -Cancer & 2 & \\
\hline During the last year, have you & 2 & \\
\hline \multicolumn{3}{|l|}{ had pain and/or stiffness in your } \\
\hline \multicolumn{3}{|l|}{ muscles and limbs that has lasted } \\
\hline \multicolumn{3}{|l|}{ for at least 3 consecutive months? } \\
\hline \multicolumn{3}{|l|}{ Have you ever been diagnosed with } \\
\hline $\begin{array}{l}\text {-Fibromyalgia (fibrositis/chronic } \\
\text { pain syndrome)? }\end{array}$ & 2 & \\
\hline $\begin{array}{l}\text {-Another long-term skeletal } \\
\text { or muscular disease? }\end{array}$ & 2 & \\
\hline \multicolumn{3}{|l|}{ Do you suffer from any long-term } \\
\hline \multicolumn{3}{|l|}{ illness of a physical or psychologic } \\
\hline \multicolumn{3}{|l|}{ nature that impairs your } \\
\hline \multicolumn{3}{|l|}{ functioning in everyday life } \\
\hline \multicolumn{3}{|l|}{ (slight, moderate or severe)? } \\
\hline -Motor ability impairment & 4 & \\
\hline -Vision impairment & 4 & \\
\hline -Hearing impairment & 4 & \\
\hline -Impairment due to physical illness & 4 & \\
\hline $\begin{array}{l}\text {-Do you have or have you ever } \\
\text { had mental health problems } \\
\text { for which you sought help? }\end{array}$ & 4 & \\
\hline $\begin{array}{l}\text {-Do you suffer from long-term } \\
\text { impairment due to mental } \\
\text { health problems? }\end{array}$ & 4 & \\
\hline \multirow[t]{2}{*}{ In the last two weeks, have you felt: } & & Mother 0.79 \\
\hline & & Father $0.8 \mathrm{I}$ \\
\hline -Troubled by anxiety? & 4 & \\
\hline -Down/depressed? & 4 & \\
\hline $\begin{array}{l}\text { How many glasses of beer, } \\
\text { wine or spirits do you usually } \\
\text { drink in the course of two weeks? }\end{array}$ & Number & \\
\hline Do you smoke (daily)? & 2 & \\
\hline
\end{tabular}

(Continued)
Table I (Continued)

\begin{tabular}{|c|c|c|}
\hline Dependent variable & $\begin{array}{l}\text { Response } \\
\text { options }\end{array}$ & $\begin{array}{l}\text { Cronbach's } \\
\text { alpha }\end{array}$ \\
\hline $\begin{array}{l}\text { Body mass index }>30 \text { (clinical data) } \\
\text { In the past year, for how much } \\
\text { of your leisure time have you been } \\
\text { physically active (hours per week)? }\end{array}$ & 2 & \\
\hline $\begin{array}{l}\text {-Low physical activity } \\
\text { (no sweating/not out of breath) }\end{array}$ & 2 & \\
\hline $\begin{array}{l}\text {-Vigorous physical activity } \\
\text { (sweating/out of breath) }\end{array}$ & 2 & \\
\hline In the last two weeks, have & 4 & Mother 0.81 \\
\hline you felt & & Father 0.84 \\
\hline -Confident and calm? & & \\
\hline -Happy and optimistic? & 4 & \\
\hline -Nervous and restless? & 4 & \\
\hline -Irritable? & 4 & \\
\hline -Lonely? & 4 & \\
\hline $\begin{array}{l}\text { Thinking about your life at the moment, } \\
\text { would you say that you are by and large } \\
\text { satisfied with life, or that you are mostly } \\
\text { dissatisfied with your life? }\end{array}$ & 7 & \\
\hline
\end{tabular}

gave their written consent. The study was approved by the Regional Committee for Medical Research Ethics and the Norwegian Data Inspectorate.

\section{Statistics}

Answers were rescaled in the same direction from the positive to the negative end. Each subscale was based on one to seven items, as shown in Table 1. Each of these items had answer scores from 1 (best) to $\mathrm{k}$ (worst). The number of alternative answers for each item varied from 2 to 4 . The item score was rescaled as (score -1$) /(k-1)$, giving a rescaled score from 0 (best) to 1 (worst). An average of these for the subscale was computed if at least half of the items on the subscale were answered, giving a subscale score in the range 0 to 1 .

We used proportional odds logistic regression to examine parental covariation with adolescent SRH. The odds ratio (OR) here has the same interpretation as the OR in standard (binary) logistic regression if a cutoff were made between any two categories of the dependent variable. Covariates included parental SRH, age of the adolescent, and a broad spectrum of variables among the parents. We carried out separate analyses for each gender, both for parents and adolescents. Unadjusted analyses, adjusted analyses for subgroups (clusters) of variables, and also multivariable analyses with all independent factors using a modified backward elimination method were conducted.

Interactions were investigated using Bonferroni correction and were found to be nonsignificant. Two-sided $P$ values $<0.05$ were considered significant. Results are 
reported as OR with $95 \%$ confidence intervals (CI) for the effect on reduced SRH, and Wald $P$ values. The SPSS 17.0 was used for statistical analysis.

\section{Results}

The distributions of SRH of parents and adolescents (number and percent) are shown in Table 2, for all four combinations with gender. Only a few individuals in these four groups described their SRH as poor. The association between parental SRH and that of their adolescent children was clearly significant for both genders. Girls' SRH was more strongly impacted by parental SRH than boys' SRH, with OR of 1.37 and 1.29 for mother and father, respectively, compared with 1.18 and 1.18 for boys, but the CI were overlapping. However, the correlation between parents and adolescents was quite low, with a Spearman rho of 0.095 (mother) $/ 0.071$ (father) for girls versus 0.053 (mother) $/ 0.055$ (father) for boys.

The unadjusted results for all independent variables (covariates) are shown in Table 3. Many of these show significant associations with lower adolescent SRH, with the highest OR for covariates measuring psychologic problems, life dissatisfaction, and lack of general well being among mothers. Among the fathers, psychologic problems, lack of general well being, and also living alone, are associated with the highest OR for impaired SRH among their adolescent children.

It is noteworthy that somatic illness, musculoskeletal illness (except for girls), high alcohol consumption, and physical inactivity among mothers were not significantly associated with their adolescent childrens' SRH. We found a similar lack of impact for fathers who, in addition, showed no impact on their children's SRH for a body mass index over 30 .

The association between parental and adolescent SRH was further studied in several models adjusting for different clusters of parental factors separately (data not shown). Structural variables were entered in the first model (adolescent age, parental education, and parent living alone). In the second model, incorporating health-related variables, we adjusted for diagnosed illnesses, musculoskeletal illness, disability, and psychologic problems among parents. In the final model we adjusted for lifestyle variables, ie, high alcohol intake, smoking, obesity, and physical inactivity among parents. All categories of variables had a modest attenuating effect on the association between parental and adolescent SRH, with the exception of the lifestyle variables among fathers.

Table 2 Cross-table for parents SRH (HUNT 2) and adolescent children's SRH (Young-HUNT), expressed as numbers and percentages

\begin{tabular}{|c|c|c|c|c|c|c|}
\hline & SRH mother & Very good & Good & $\begin{array}{l}\text { Not very } \\
\text { good }\end{array}$ & Poor & Total \\
\hline \multirow[t]{9}{*}{ SRH boys/girls } & Very good & $256 / 204(39.6 / 31.0)$ & $749 / 503(34.0 / 22.7)$ & $202 /|2|(3|.3 /| 8.6)$ & $8 / 5(19.5 / 15.6)$ & $1215 / 833(34.4 / 23.4)$ \\
\hline & Good & $335 / 396(51.8 / 60.1)$ & I240/I465 (56.3/66.I) & $380 / 442(58.9 / 67.8)$ & $30 / 20(73.2 / 62.5)$ & $1985 / 2323(56.2 / 65.3)$ \\
\hline & Not very good & $50 / 57$ & $200 / 238$ & $58 / 83$ & $3 / 7$ & $311 / 385$ \\
\hline & & $(7.7 / 8.6)$ & $(9.1 / 10.7)$ & $(9.0 / 12.7)$ & $(7.3 / 21.9)$ & $(8.8 / 10.8)$ \\
\hline & Poor & $6 / 2$ & $12 / 9$ & $5 / 6$ & $0 / 0$ & $23 / 17$ \\
\hline & & $(0.9 / 0.3)$ & $(0.5 / 0.4)$ & $(0.8 / 0.9)$ & $(0.0 / 0.0)$ & $(0.7 / 0.5)$ \\
\hline & Total & $647 / 659$ & $2201 / 2215$ & $645 / 652$ & $41 / 32$ & $3534 / 3558$ \\
\hline & & $(100 / 100)$ & $(100 / 100)$ & $(100 / 100)$ & $(100 / 100)$ & $(100 / 100)$ \\
\hline & SRH father & Very good & Good & $\begin{array}{l}\text { Not very } \\
\text { good }\end{array}$ & Poor & Total \\
\hline \multirow[t]{9}{*}{ SRH boys/girls } & Very good & $180 / 148$ & $703 / 458$ & $14 \mid / 111$ & $14 / 5$ & $1038 / 722$ \\
\hline & & $(37.1 / 30.8)$ & $(35.1 / 23.0)$ & $(27.8 / 23.8)$ & $(40.0 / 12.8)$ & $(34.2 / / 24.3)$ \\
\hline & Good & 259/29I (53.4/60.6) & II $25 / 1335(56.1 / 67.1)$ & $303 / 289(59.8 / 61.9)$ & $18 / 26(5 \mid .4 / 66.7)$ & $|705 /| 94 \mid(56.3 / 65.2)$ \\
\hline & Not very good & $43 / 40$ & $163 / 191$ & $59 / 64$ & $3 / 8$ & $268 / 303$ \\
\hline & & $(8.9 / 8.3)$ & $(8.1 / 9.7)$ & $(11.6 / 13.7)$ & $(8.6 / 20.5)$ & $(8.8 / 10.2)$ \\
\hline & Poor & $3 / 1$ & $13 / 7$ & $4 / 3$ & $0 / 0$ & $20 / 11$ \\
\hline & & $(0.6 / 0.2)$ & $(0.6 / 0.4)$ & $(0.8 / 0.6)$ & $(0.0 / 0.0)$ & $(0.7 / 0.4)$ \\
\hline & Total & $485 / 480$ & $2204 / 1991(100 / 100)$ & $507 / 467$ & $35 / 39$ & $3031 / 2977$ \\
\hline & & $(100 / 100)$ & & $(100 / 100)$ & $(100 / 100)$ & $(100 / 100)$ \\
\hline
\end{tabular}


Table 3 Unadjusted ordinal regression analyses with adolescent SRH as dependent variable, and separate analyses for boys and girls. Reference category, best SRH

\begin{tabular}{|c|c|c|c|c|c|}
\hline & $\begin{array}{l}\text { Boys/girls } \\
\text { (n) }\end{array}$ & $\begin{array}{l}\text { OR }(\mathrm{Cl}) \\
\text { boys }\end{array}$ & $\begin{array}{l}P \text { value } \\
\text { boys }\end{array}$ & $\begin{array}{l}\text { OR }(\mathrm{Cl}) \\
\text { girls }\end{array}$ & $\begin{array}{l}P \text { value } \\
\text { girls }\end{array}$ \\
\hline \multicolumn{6}{|l|}{ Father } \\
\hline Lower SRH & $3031 / 2977$ & $1.18(1.05-1.31)$ & 0.005 & $1.29(1.14-1.46)$ & $<0.001$ \\
\hline Lower education & $3017 / 2954$ & $1.54(1.25-1.90)$ & $<0.001$ & $1.49(1.19-1.86)$ & $<0.001$ \\
\hline Living alone & $3008 / 2956$ & $2.06(1.35-3.14)$ & 0.001 & $1.98(1.28-3.08)$ & 0.002 \\
\hline Diagnosed somatic illness & $444 I / 4389$ & $1.05(0.86-1.27)$ & 0.643 & $0.95(0.76-1.18)$ & 0.634 \\
\hline Musculoskeletal illness & $444 I / 4389$ & $1.10(0.97-1.24)$ & 0.143 & $0.95(0.84-1.08)$ & 0.465 \\
\hline Disability & $444 I / 4389$ & $1.34(0.97-2.04)$ & 0.177 & $1.85(1.80-2.90)$ & 0.008 \\
\hline Psychologic problems & $3034 / 2981$ & I.5I (0.92-2.49) & 0.099 & $2.2 \mathrm{I}(\mathrm{I} .28-3.8 \mathrm{I})$ & 0.004 \\
\hline High alcohol intake $(>85 \mathrm{pct})$ & $2667 / 2598$ & $\mathrm{I} .0 \mathrm{I}(0.83-1.23)$ & 0.923 & $1.15(0.93-1.43)$ & 0.194 \\
\hline Smoking & $2916 / 2886$ & $1.42(1.21-1.67)$ & $<0.00$ I & I.I5 (0.97-I.35) & 0.103 \\
\hline $\mathrm{BMI}>30$ & $304 \mathrm{I} / 2997$ & I.I5 (0.94-I.42) & 0.179 & $\mathrm{I} .06(0.85-1.32)$ & 0.595 \\
\hline Physical inactivity & $2957 / 2908$ & I.I8 (0.92-I.50) & 0.200 & $1.19(0.92-1.54)$ & 0.191 \\
\hline Life dissatisfaction & $3032 / 2988$ & $1.40(1.13-1.72)$ & 0.002 & I.47 (I.I7-I.86) & 0.001 \\
\hline Lack of general well being & $2882 / 2866$ & $2.45(1.5 \mathrm{I}-3.97)$ & $<0.001$ & $2.65(1.62-4.34)$ & $<0.001$ \\
\hline \multicolumn{6}{|l|}{ Mother } \\
\hline Lower SRH & $3534 / 3558$ & $1.18(1.07-1.30)$ & 0.001 & $1.37(1.23-1.53)$ & $<0.001$ \\
\hline Lower education & $3529 / 3565$ & $1.59(1.30-1.94)$ & $<0.001$ & $1.57(1.30-1.89)$ & $<0.001$ \\
\hline Living alone & $3501 / 3547$ & $1.34(1.13-1.60)$ & 0.001 & $1.57(1.30-1.89)$ & $<0.001$ \\
\hline Diagnosed somatic illness & $444 I / 4389$ & $1.13(0.93-1.38)$ & 0.206 & $1.22(0.99-1.5 \mathrm{I})$ & 0.600 \\
\hline Musculoskeletal illness & $444 \mid / 4389$ & $1.01(0.89-1.13)$ & 0.926 & $1.16(1.02-1.31)$ & 0.020 \\
\hline Disability & $444 I / 4389$ & $1.68(1.09-2.59)$ & 0.019 & $2.32(1.47-3.67)$ & $<0.001$ \\
\hline Psychologic problems & $3536 / 3574$ & $1.85(1.27-2.69)$ & 0.001 & $2.78(I .84-4.21)$ & $<0.001$ \\
\hline High alcohol intake (>85 pct) & $2898 / 2927$ & $0.90(0.74-1.09)$ & 0.276 & $1.08(0.88-1.34)$ & 0.465 \\
\hline Smoking & $3379 / 3429$ & $1.29(1.13-1.48)$ & $<0.001$ & $1.59(1.37-1.83)$ & $<0.001$ \\
\hline $\mathrm{BMI}>30$ & $355 I / 3590$ & $1.28(1.06-1.55)$ & 0.011 & $1.32(1.08-1.61)$ & 0.006 \\
\hline Physical inactivity & $3417 / 3485$ & $1.19(0.93-1.53)$ & 0.164 & $1.24(0.96-1.61)$ & 0.101 \\
\hline Life dissatisfaction & $3523 / 3556$ & $1.60(1.08-2.35)$ & 0.018 & $3.34(2.22-5.12)$ & $<0.001$ \\
\hline Lack of general well being & $3367 / 3410$ & $1.97(1.31-2.97)$ & 0.001 & $2.33(1.50-3.63)$ & $<0.001$ \\
\hline
\end{tabular}

Abbreviations: OR, odds ratio; $\mathrm{Cl}$, confidence interval; $\mathrm{SRH}$, self-reported health; BMI, body mass index.

Table 4 gives the results after adjusting for all original independent variables, and then using a modified backward elimination method of nonsignificant variables. Parental SRH was kept in the analyses. Variables that significantly predicted adolescent SRH in at least one of the four analyzed comparisons were also used in the multivariable model. The associations between parental and adolescent SRH then vanished compared with the unadjusted model in Table 3. The remaining significant variables among mothers were lower education, living alone, smoking (for girls), and lower life satisfaction (for girls). Among fathers, the remaining significant variables were lower education, living alone (for girls), smoking (for boys), and lower general well being (for girls).

Some of the parental covariates in our study were strongly correlated, notably life dissatisfaction and lack of general well-being (Spearman rho 0.6). Because of the possibility of multicollinearity, we also conducted the final multivariable analyses, entering only one of these two variables at a time. With general well being excluded from the model, maternal life dissatisfaction strongly impacted daughters' SRH $(\mathrm{OR}=2.58, P<0.001)$ but not sons' SRH. Paternal life dissatisfaction impacted boys' $\mathrm{SRH}(\mathrm{OR}=1.75, P=0.025)$. With life dissatisfaction excluded from the model, general well being among mothers did not significantly impact their adolescent children's SRH, whereas fathers' well being strongly impacted both their daughters' $(\mathrm{OR}=2.06$, $P=0.011)$ and their sons' SRH $(\mathrm{OR}=1.90, P=0.019)$.

\section{Discussion}

In this study we found a rather weak association between parental SRH and adolescent children's own SRH rating. This association was also modestly attenuated when adjusted for several clusters of covariates, with the exception of health behavior among fathers. Several parental factors other than SRH were more strongly associated with adolescent children's SRH in unadjusted analyses. Among these were psychologic problems, living alone, disability, and life 
Table 4 Ordinal regression analyses adjusted for all independent variables in four separate groups with adolescent SRH as the dependent variable. Backward elimination until variables are significant in at least one group and parental SRH included in all groups

\begin{tabular}{|c|c|c|c|c|}
\hline \multicolumn{5}{|l|}{ Mothers } \\
\hline Boys $(n=3107)$ Girls $(n=3158)$ & OR (Cl) & $P$ value & OR (Cl) & $P$ value \\
\hline Age of adolescent & $1.05(1.01-1.09)$ & 0.014 & $1.05(1.01-1.09)$ & 0.024 \\
\hline Lower SRH mother & $1.10(0.98-1.24)$ & 0.114 & $1.13(1.00-1.29)$ & 0.055 \\
\hline Lower education mother & $1.38(I .10-1.7 I)$ & 0.005 & $1.35(1.07-1.70)$ & 0.012 \\
\hline Mother living alone & $1.26(1.04-1.53)$ & 0.016 & $1.40(1.14-1.70)$ & 0.001 \\
\hline Smoking mother & $1.14(0.98-1.32)$ & 0.089 & $1.40(1.20-1.64)$ & $<0.001$ \\
\hline Life dissatisfaction mother & $0.7 \mathrm{I}(0.4 \mathrm{I}-\mathrm{I} .23)$ & 0.222 & $3.14(1.73-5.70)$ & $<0.001$ \\
\hline Lack of general well being mother & $1.64(0.93-2.88)$ & 0.087 & $0.72(0.40-1.32)$ & 0.295 \\
\hline \multicolumn{5}{|l|}{$\begin{array}{l}\text { Fathers } \\
\text { Boys }(n=2696) \text { Girls }(n=2675)\end{array}$} \\
\hline Age of adolescent & $1.04(1.00-1.08)$ & 0.084 & $1.08(1.04-1.13)$ & $<0.001$ \\
\hline Lower SRH father & $1.06(0.92-1.22)$ & 0.419 & $1.15(1.00-1.34)$ & 0.057 \\
\hline Lower education father & $1.33(1.06-1.67)$ & 0.014 & $1.32(1.03-1.68)$ & 0.027 \\
\hline Father living alone & $1.23(0.98-1.55)$ & 0.071 & $1.48(1.15-1.91)$ & 0.002 \\
\hline Smoking father & $1.28(1.08-1.52)$ & 0.004 & $1.06(0.89-1.26)$ & 0.549 \\
\hline Life dissatisfaction father & $1.66(0.91-3.02)$ & 0.095 & $0.88(0.47-1.64)$ & 0.658 \\
\hline Lack of general well being father & $1.39(0.73-1.95)$ & 0.318 & $2.34(1.19-4.60)$ & 0.014 \\
\hline
\end{tabular}

Abbreviations: $\mathrm{OR}$, odds ratio; $\mathrm{Cl}$, confidence interval; SRH, self-reported health.

dissatisfaction. Furthermore, lack of general well being among parents seemed especially important. In a final multivariable analysis, lower education, living alone, smoking, and less general well being among parents remained significant factors for adolescents' SRH. It is notable that typical medical and lifestyle variables among parents seemed to lack importance for adolescent SRH. The associations were generally stronger for girls than for boys for both parents, although the CI for these factors overlapped.

A study in Slovak and Dutch adolescents demonstrated both gender and country differences in parental influence on SRH. ${ }^{17}$ The gender differences in parental influence in our study were not conspicuous. The results of our study contrast with the strong genetic influence on SRH found in several twin studies. ${ }^{9-11}$ The adolescents in our study carried with them both a genetic and a social heritage from their parents, but their SRH seemed less impacted by parental factors. Thus, it may be that the impact on SRH from the many "horizontal" influences in the adolescent period of life is especially strong. This observation means that healthpromoting actions from wider society have a greater chance of success during adolescence. The importance of a more proactive health promotion from early life in the building of a new framework for health and for disease prevention has also been underscored by other authors. ${ }^{18}$

In our previous research, we have found that adolescent SRH is a broad multifactorial composite, although one in which typical medical conditions are not the most important factors. ${ }^{5,6}$ The current study shows the same results for medical conditions among the adolescents' parents too, as well as for several parental lifestyle variables, except for smoking. This contrasts with a Swedish twin study where heredity was found to be an important component behind individual differences in lifestyle connected to physical activity. ${ }^{19}$ For parental smoking, however, our results agree with a Danish study, ${ }^{20}$ although we should be aware that smoking is also associated with socioeconomic status.

In contrast, high parental alcohol intake was not associated with adolescent SRH in our study. This agrees with another Danish study where no association could be shown between early onset of alcohol consumption and parental smoking, drinking, and socioeconomic or marital status. ${ }^{21-26}$

The significant associations between structural factors, such as parental education and living alone, in our final multivariable analyses indicate that other parental social factors can be more important for adolescent SRH than parental SRH. These point to the well-known influence of socioeconomic status on SRH. A role of parental education, as well as adolescents' own education, school achievement, and perceived socioeconomic status on SRH has been found in several studies. ${ }^{23-26} \mathrm{~A}$ Canadian study found lower SRH in single fathers compared with partnered fathers, but this was found to be due to the economic and social disadvantages associated with raising children alone. ${ }^{27}$

The strong association in our study between lack of parental well being and especially adolescent girls' SRH is striking. 
Interestingly, general well being also showed the highest OR for the construct of adolescent SRH in our earlier studies. ${ }^{5,6}$ Happiness and life satisfaction have also been found by others to predict better SRH later in life. ${ }^{28}$ In conclusion, we have found only limited associations between parental SRH and that of their adolescent children. More traditional healthrelated and lifestyle factors, with the exception of parental smoking, also seem to be of little significance, whereas social factors such as parental educational level, living alone, and parental well-being seem to be most important.

The response rate was good in the survey among adolescents, but the combination of parental and adolescent data led to a substantial loss of subjects. This may limit both the external and internal validity of the study. It is possible that information from parents with impaired SRH was underreported, so that associations between parental and adolescent SRH might be stronger than estimated by our study. The external validity of the study may also be restricted by the fact that data for our study were collected 15 years ago. Also, the study cannot rule out a stronger association with parental SRH as the adolescents grow older and reach adult age.

$\mathrm{SRH}$ is a central target for mass strategies in public health promotion, and can also serve as a simple way of measuring the success of these strategies. As SRH in our study seems less predetermined by "nature" than by "nurture"29 during adolescence than might be expected from a number of genetic studies, greater efforts directed to the important context factors contributing to positive SRH among both parents and adolescents is recommended.

\section{Acknowledgment}

We would like to thank Patrik Stolt of the Institute of Environmental Medicine, Karolinska Institutet, Stockholm, Sweden, for advice and support, and HUNT-Norway for their contribution of data for this study.

\section{Disclosure}

The authors report no conflicts of interest in this work.

\section{References}

1. Currie C, Nic Gabhain S, Godeau E, et al (editors). Inequalities in young people's health. Health behaviour in school-aged children (HBSC) 2005/2006. HBSC International Coordinating Centre (Child and Adolescent Health Research Unit). Edinburgh: World Health Organization Report; 2008.

2. Eriksson HG, von Celsing AS, Wahlström R, Janson L, Zander V, Wallman T. Sickness absence and self-reported health: A populationbased study of 43,600 individuals in central Sweden. BMC Public Health. 2008;8:426.
3. Eder A. Risk factor loneliness. On the interrelations between social integration, happiness and health in 11-, 13- and 15-year schoolchildren in 9 European countries. Health Promot Int. 1990;5:19-32.

4. Council of the European Union. Council Resolution on the health and well-being of young people. 2905th Education, Youth and Culture Council meeting, Brussels; 2008. Available at: http://www.consilium. europa.eu/uedocs/cms_Data/docs/pressdata/en/educ/104209.pdf. Accessed Aug 05, 2010.

5. Breidablik HJ, Meland E, Lydersen S. Self-rated health in adolescence: A multifactorial composite. Scand J Public Health. 2008;36(1): $12-20$.

6. Breidablik HJ, Meland E, Lydersen S. Self-rated health during adolescence: Stability and predictors of change (Young-HUNT study, Norway). Eur J Public Health. 2009;19(1):73-78.

7. Silventoinen K, Posthuma D, Lahelma E, Rose RJ, Kaprio J. Genetic and environmental factors affecting self-rated health from age 16-25: A longitudinal study of Finnish twins. Behav Genet. 2007;37(2): 326-333.

8. Romeis JC, Scherrer JF, Xian H, et al. Heretability of self-reported health. Health Serv Res. 2000;35(5):995-1010.

9. Christensen K, Holm NV, McGue M, Corder L, Vaupel JW. A Danish population-based twin study on general health in the elderly. $J$ Aging Health. 1999;11(1):49-64.

10. Harris JR, Pedersen NL, McClearn GE, Plomin R, Nesselroade JR. Age differences in genetic and environmental influences for health from the Swedish Adoption/Twin Study of Aging. J Gerontol. 1992;47(3): 213-220.

11. Røysamb E, Tambs K, Reichborn-Kjennerud T, Neale MC, Harris JR. Happiness and health: Environmental and genetic contributions to the relationship between subjective well-being, perceived health, and somatic illness. J Pers Soc Psychol. 2003;85:1136-1146.

12. Leinonen R, Kaprio J, Jylha M, et al. Genetic influences underlying self-rated health in older female twins. J Am Geriatr Soc. 2005;53(6): 1002-1007.

13. Holmen J, Midhjell K, Krüger Ø, et al. The Nord-Trøndelag Health Study 1995-97 (HUNT 2): Objectives, contents, methods and participation. Norsk Epidemiologi. 2003;13(1):19-32.

14. Tambs K, Moum T. How well can a few questionnaire items indicate anxiety and depression? Acta Psychiatr Scand. 1993;87(5):364-367.

15. Rosenberg M. Society and Adolescent Self-image. Princeton, NJ: Princeton University Press; 1965.

16. Moum T, Næss S, Sørensen T, et al. Hypertension labelling, life events, and psychological well-being. Psychol Med. 1990;20(3):635-646.

17. Sleskova M, Tuinstra J, Madarasova Geckova A, et al. Influence of parental employment status on Dutch and Slovak adolescent's health. BMC Public Health. 2006;6:250.

18. Shonkoff JP, Boyce WT, McEwen BS. Neuroscience, molecular biology, and the childhood roots of health disparities: Building a new framework for health promotion and disease prevention. JAMA. 2009;301(21):2252-2259.

19. Carlsson S, Andersson T, Lichtenstein P, Michaëlsson K, Ahlbom A. Genetic effects on physical activity: Results from the Swedish Twin Registry. Med Sci Sports Exerc. 2006;38(8):1396-1401.

20. Osler M, Clausen JO, Ibsen KK, Jensen GB. [Smoking as social heritage. Children whose mothers are smokers are more likely to become smokers as adults]. Ugeskr Laeger. 1996;158(17):2384-2387. Danish.

21. Wium-Andersen MK, Wium-Andersen IK, Becker U, Thomsen SF. [Onset of alcohol consumption in 7-18-year-old children and adolescents]. Ugeskr Laeger. 2009;171(46):3345-3349. Danish.

22. King SM, Keyes M, Malone SM, et al. Parental alcohol dependence and the transmission of adolescent behavioral disinhibition: A study of adoptive and non-adoptive families. Addiction. 2009;104(4):578-586.

23. Kestila L, Koskinen S, Martelin T, Rahkonen O, Pensola T, Aro H, et al. Determinants of health in early adulthood: what is the role of parental education, childhood adversities and own education? Eur J Public Health. 2006;16(3):306-315. 
24. Koivusilta LK, Rimpela AH, Kautiainen SM. Health inequality in adolescence. Does stratification occur by familial social background, family affluence, or personal social position? BMC Public Health. 2006; 6:110.

25. Karademas EC, Peppa N, Fotiou A, Kokkevi A. Family, school and health in children and adolescents: Findings from the $2006 \mathrm{HBSC}$ study in Greece. J Health Psychol. 2008;13(8):1012-1020.

26. Goodman E, Huang B, Schafer-KalkhoffT, Adler NE. Perceived socioeconomic status: A new type of identity that influences adolescents' self-rated health. J Adolesc Health. 2007;41(5):479-487.
27. Janzen BL, Green K, Muhajarine N. The health of single fathers: Demographic, economic and social correlates. Can J Public Health. 2006;97(6):440-444

28. Siahpush M, Spittal M, Singh GK. Happiness and life satisfaction prospectively predict self-rated health, physical health, and the presence of limiting, long-term health conditions. Am J Health Promot. 2008;23(1):18-26.

29. Helman CG. New bodies, new selves: Genetics and biotechnology. In: Helman CG, editor. Culture, Health and Illness. 5th ed. London: Hodder Arnold; 2007.

\section{Publish your work in this journal}

Adolescent Health, Medicine and Therapeutics is an international, peer-reviewed, open access journal focusing on health, pathology, and treatment issues specific to the adolescent age group. All aspects of health maintenance, preventative measures and disease treatment interventions are addressed within the journal and practitioners from all disciplines are invited to submit their work as well as healthcare researchers and patient support groups.. The manuscript management system is completely online and includes a very quick and fair peerreview system. Visit http://www.dovepress.com/testimonials.php to read real quotes from published authors.

Submit your manuscript here: http://www.dovepress.com/adolescent-health-medicine-and-therapeutics-journal 